\title{
The Multifaceted Role of Information and Communication Technology (ICT) in Innovation: Evidence from Chinese Manufacturing Firms
}

\author{
Zhongjuan Sun \\ College of Business Administration, Capital University of Economics and Business, China. Email: () \\ Jun Hou* \\ Overseas Development Institute, United Kingdom. Email: j.hou@odi.org \\ Jizhen $\mathrm{Li}^{*}$ \\ School of Economics and Management, Tsinghua University, China. Email: lijzh@ sem.tsinghua.edu.cn
}

\begin{abstract}
Using a sample of 1397 manufacturing firms in China, this study explores how information and communication technology (ICT) stimulates innovation performance through interaction with investment in internal and external knowledge. The results of this study reveal that the adoption of ICT not only contributes to innovation by directly enhancing its output, but also affects the creation of knowledge along two different paths in Chinese manufacturing firms. Specifically, ICT mediates research and development (R\&D) to foster innovative sales and it is an effective moderator in leveraging externally acquired knowledge.
\end{abstract}

Keywords: ICT, innovation, moderating effect, mediating effect 


\section{Introduction}

Emerging in the middle of the twentieth century, the ICT industry has developed rapidly (Yu et al., 2008) and it now plays a pivotal role in establishing firm competitiveness and driving economic growth (Takahashi et al., 2004; Ollo-López \& Aramendía-Muneta, 2012). For example, economic growth in countries that are technically advanced in ICT, such as Japan (Jorgenson \& Nomura, 2005), Korea (Shin \& Park, 2007) and Finland (Jalava \& Pohjola, 2007), is dominated by investments in ICT and productivity growth in both industries and the economy as a whole (Lee, Kim \& Park, 2009). Further, ICT is now widely used: the percentage of the population using the Internet has been growing at an average rate of double digits over the past ten years. In the developed world, this figure reached almost 77 percent by 2013 and in the developing world it reached 31 percent. $^{1}$

The role of ICT in economic development has received increasing academic interest (Lee, Kim \& Park, 2009; Tambe \& Hitt, 2012; Gao \& Hitt, 2012; Tafti, Mithas \& Krishnan, 2013). In general, previous studies have largely focused on three issues: the contribution of ICT to economic growth (Bakhshi \& Larsen, 2005), the nature of ICT itself (Corrocher et al., 2007; Shin \& Park, 2007; Sorenson et al., 2006) and the impacts of specific ICTs (e.g., mobile networks or broadband) on innovation (Chen, Watanabe \& Griffy-Brown, 2007). Previous studies have also explored the impacts of ICT adoption on firm innovation performance (Hall, et al., 2012), operation efficiency (Hidalgo \& López, 2009) and the internationalization of investment in ICT research and development (R\&D) (Nepelski \& Prato, 2012). However, findings with respect to the specific ways ICT affects product innovation and process innovation remain inconclusive. In particular, the mechanism by which ICT interacts with knowledge sourcing and subsequently contributes to innovation performance is still to be explored.

This study examines the potential associations between innovation-oriented ICT and different types of knowledge-sourcing activities (in-house R\&D and technology purchasing). ${ }^{2}$ It intends to explore ICT's multifaceted nature and to seek answers to the following questions: What specific roles does ICT play in the processes of knowledge creation? How does ICT interact with different types of innovation inputs and facilitate them to generate innovation? Are there potential mediating or moderating effects that exist between ICT and knowledge sources that may expedite the technological upgrading of Chinese manufacturing firms? In

\footnotetext{
${ }^{1}$ Data source: http://www.itu.int/net/pressoffice/press_releases/2013/41.aspx\#.Vz0YL-x7LX4

2 Innovation-oriented ICT refers to investments in ICT that are specifically deployed for the purpose of supporting knowledge-creation processes such as hardware and software, technical equipment, business components and networks for knowledge acquisition, integration, learning and development.
} 
line with previous studies, the results of this research confirm that the innovation performance of Chinese manufacturing firms is directly affected by ICT adoption (Hall, et al., 2012). In addition, mediating effects of ICT on R\&D and moderating effects of ICT on technology purchasing are also identified, suggesting that ICT contributes to innovation in multiple ways.

One existing gap in the literature pertaining to innovation is the limited evidence concerning the strength of innovation intensity. Previous studies only use the product innovation equation to capture the output of the innovation, despite the fact that the processes of innovation are another equally important measure of outcome. Previous research has either largely ignored this issue or merely incorporated a dummy to address it. ${ }^{3}$ The current study seeks to enlarge the scope of innovation performance research by estimating a separate output equation for the processes of innovation. The impacts of ICT on innovation will also be examined in terms of product and process innovations respectively.

The paper is structured as follows: Section 2 details the hypotheses relevant to the role of ICT in the knowledge-creation process; Section 3 introduces the methodology, model specifications and data; Section 4 presents empirical analyses; and Section 5 discusses the empirical results and summarizes their implications.

\section{Theory Framework and Hypothesis}

\subsection{Theory Framework}

ICTs refer to a broad range of both simple and complicated technologies that facilitate communication for innovation (Oladipo \& Andrew, 2012). A list of examples would include traditional telephones, cell phones, e-mail, intra/internets, Telephone-conferencing, video conferencing, Web-conferencing, and group decision support software (Pepper \& Larson, 2006). This section developed an analytical framework to explore the direct innovation impacts of ICT, as well as its indirect roles in fostering knowledge creation.

Innovation system approaches are increasingly adopted to discover intrinsic relationships between cross- and multi-levels of innovation (Pepper \& Larson, 2006). Such approaches emphasize that a firm's ability to successfully commercialize a new product depends not only on its own technology strategy, but also on the implementation of supporting practices adopted by a wide range of organizations in the firm's innovation system (Cohen \& Levinthal,

\footnotetext{
${ }^{3}$ Llorca (2002) analyses the impact of process innovations on productivity growth using number of product and process innovations. However, the exact number of process innovations is not available and is proxied by a categorical variable. Another study was conducted by Peters (2005) in which the output or success of process innovation is measured as the share of cost reduction in unit costs due to process innovations, which can therefore be interpreted as cost-weighted innovation counts. This indicator and its corresponding definition were given in the Community Innovation Surveys (CIS) Germany.
} 
1990). The framework presented in Figure 1 uses three key input elements to explain the knowledge-creation process: internal $\mathrm{R} \& \mathrm{D}$, external technology purchasing and ICT. Not only will these three factors each support innovation, the potential synergies among them may also effectively contribute to the extent of the innovation. In particular, the figure emphasizes the multifaceted nature of ICT and canvasses potential interactions between ICT and innovation inputs, as well as suggesting how these interactions can affect an organization's innovation performance.

As a tool for communication, ICT is treated as an efficient channel for firms to gain access to advanced technological information. As an instrumental input, ICT effectively interacts with knowledge sources for innovation and further enhances innovation performance. Organization learning theory (Wiseman \& Anderson, 2012) suggests that the adoption of ICT practices increases the effectiveness of both internal $R \& D$ and external technology purchasing. Hence, the knowledge creation generated from $R \& D$ investment and external technology purchasing is expected to be greater for firms with compatible ICT support.

ICT is a channel for accumulating an organization's capabilities, such as its ability to acquire knowledge and its propensity for integration, learning and development (Wiseman \& Anderson, 2012). ICT provides necessary infrastructure to guarantee and reinforce the innovation return on R\&D investment (Hicks \& Katz, 1996). In such circumstances, ICT serves as a mediator in the relationship between $R \& D$ and innovation, as shown by the horizontal arrows in Figure 1. The influence of $R \& D$ on innovation is partially identified as an indirect influence through ICT and the corresponding association between R\&D and innovation is located by tracing the pathways from innovation back to ICT and from ICT back to R\&D (Loehlin, 1987). ${ }^{4}$ Conversely, ICT may act as a moderator in the association between innovation inputs and outcomes by interacting with input variables, in-house $R \& D$ and/or technology purchasing (Rao, 2007). As depicted by the vertical arrows in Figure 1, the effects of R\&D and technology purchasing on innovation performance are dependent on the presence of ICT (Aiken and West, 1991). It is worth noting that, as a moderator, ICT affects the strength of the relationship between technology purchasing and innovation performance. When ICT performs as a mediator, it not only strengthens the existing relationship between in-house R\&D and innovation performance, but the likelihood of adopting ICT is reinforced

\footnotetext{
${ }_{4}^{4}$ The mediating effect of ICT here refers to partial mediation as discussed by Baron and Kenny (1986). It is different from complete mediation that defines the mediator as a must-be-satisfied condition to form the relationship between the explanatory variable and the dependent variable. When the complete mediator is controlled, the explanatory variable will no longer affect the dependent variable when the complete mediator is controlled. The partial mediation is the case in which the path from the explanatory variable to the dependent variable is reduced in an absolute size but is still different from zero when the mediator is controlled. In the current setting, ICT partially mediates R\&D by increasing its innovation effects while $\mathrm{R} \& \mathrm{D}$ itself also produces directly innovation impacts.
} 
by the improvement of R\&D. The difference between these two effects lies in the potential backward linkage between ICT and knowledge sourcing. When ICT mediates in-house R\&D, the R\&D reinforces ICT simultaneously. Such effects do not appear when ICT performs as a moderator.

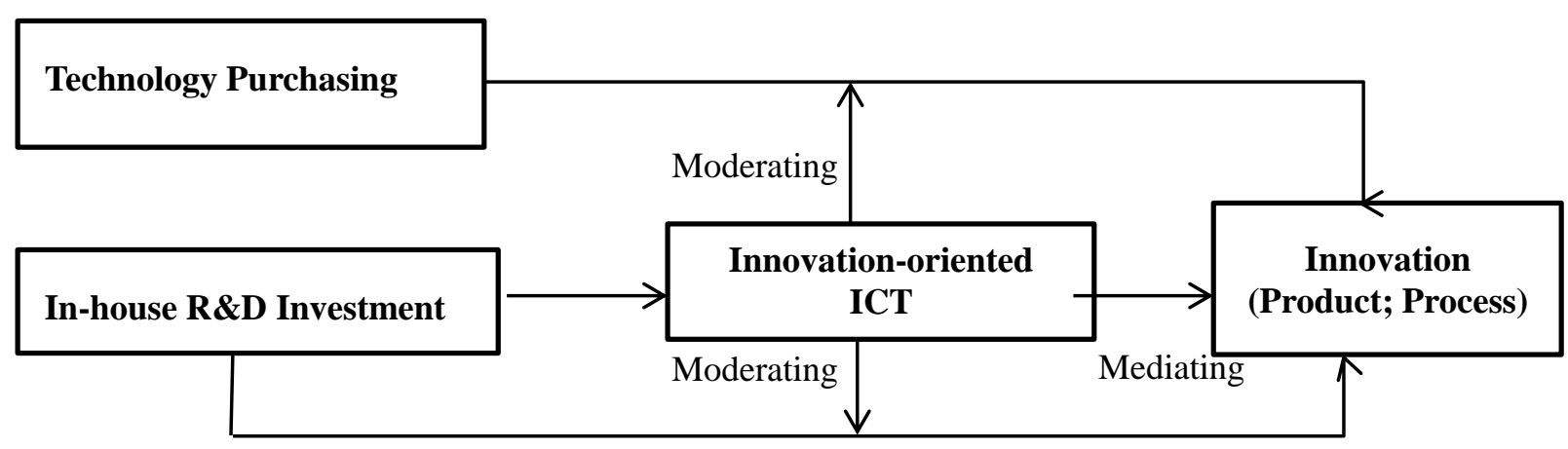

Figure 1. The multifaceted role of ICT in innovation

\subsection{The Direct Innovation Impact of ICT}

ICT improves the efficiency of knowledge creation and information sharing in various ways. As a source of innovation, ICT (e.g., the Internet) is a knowledge-acquisition channel through which firms can gain access to advanced intelligence and share it with organization stakeholders regardless of time restrictions and geographical boundaries. In this sense, ICT can be used as a corporate channel for one-way information acquisition, dissemination and data access across all organizational levels (Bafoutsou \& Mentzas, 2002).

The amount of information and knowledge in a modern organization that needs to be stored and shared depends on the extent to which the organization is exposed to the global technology market. A study by the Organization for Economic Cooperation and Development (OECD, 2010a) reveals the role of ICT in fostering innovation across nine countries; the results suggest that higher numbers of general web facilities increase the likelihood of innovation. Today, even in developing countries, firms cannot afford to ignore new ICTs that radically reduce the time needed to create and communicate knowledge (Nonaka \& Nishiguchi, 2001).

Further, ICT is an effective way to leverage externally acquired codified knowledge (Zack, 1999). Empirically, even when based on different indicators, the relationship between ICT and firm performance is generally positive (Bresnahan, Brynjolfsson \&Hitt, 2002). This gives rise to the following hypothesis:

Hypothesis 1: The adoption of innovation-oriented ICT is positively associated with the innovation performance of organizations. 


\subsection{The Mediating Role of ICT in In-house R\&D}

The application of ICT has been gradually acknowledged as an essential component of R\&D activities (Hicks \& Katz, 1996). ICT has assisted organizations in the knowledge-production stage to develop capabilities to conduct in-house knowledge creation (Nonaka \& Teece, 2001). R\&D also relies heavily on computers and software for modeling, simulation and analysis. Without access to innovation-oriented ICT infrastructure it is almost impossible to undertake R\&D activities. With regard to the formation of innovation networks, the adoption of ICT allows firms in developing countries to shift to more open, collaborative and network-centered innovation practices (Christensen \& Maskell, 2003). This is particularly important for R\&D activities today because research is increasingly conducted by research teams that collaborate across organizations and countries (Kalakota \& Robinson, 2000). Therefore, access to ICT infrastructure is necessary for all members of the R\&D ecosystem to undertake long-distance collaboration and firms are inclined to adopt compatible ICT applications when engaging in collaborative R\&D.

Previous studies have also highlighted the role of ICT in upgrading the capacity of organizations to absorb knowledge across different stages of innovation (Pavitt, 2003). ICT enhances innovation improvements in internal $R \& D$ through concept development, product or process design and project management (Gao \& Hitt, 2012). During this process, ICT assists with data communications, knowledge sharing and knowledge accumulation (Liberatore \& Stylianou, 1995). In addition, ICT can improve project management and thereby promote innovation, as managing $R \& D$ activities has become a complicated procedure (Girotra et al. 2007). Given its important role, investing in R\&D reciprocally increases the likelihood of ICT adoption. Therefore, we argue that ICT is an essential component of the relationship between R\&D and knowledge creation:

Hypothesis 2: ICT adoption positively mediates the innovation impacts of in-house $R \& D$; the intensity of innovation generated from $R \& D$ investment will be strengthened by the presence of ICT and, simultaneously, the development of in-house $R \& D$ will increase the likelihood of ICT being adopted.

\subsection{The Moderating Role of ICT in the Purchasing of Technology}

Firms are expected to engage in a variety of knowledge-sourcing strategies in response to their internal resources and the external technological environment (Lai \& Weng, 2016). Faced with accelerated technological changes and increasing international competition, firms inevitably utilize external sources as a means of enhancing innovative performance and 
reinforcing competitive advantage (Kang et al., 2015). External technologies can be viewed as a way of expanding a firm's knowledge base, one of the determinants of innovativeness according to technology upgrade theories (Griliches, 1990; Henderson \& Cockburn, 1996). Meanwhile, the acquired technology may be potentially and inventively recombined and integrated with the local technology base, according to economies of scale and scope (Henderson \& Cockburn, 1996).

Another of ICT's crucial roles in the knowledge-creation process is to moderate the strength of externally acquired knowledge (Rao, 2007). The application of ICT provides firms with great support in decoding and comprehending the codified content of external technologies. Solid local ICT facilities support external knowledge acquisition by allowing firms to merge their own knowledge base with unfamiliar external sources to identify, assimilate and translate purchased technologies for local use. Moreover, ICT practices are a way of diffusing intra-organizational knowledge, which strengthens knowledge communication between agents within the organization (Ziesemer, 2002). As discussed above, higher ICT levels accordingly result in better absorption and integration of purchased technology because ICTs, such as Intranets or computer-based group projects, are tools dedicated to internal communication (Nguyen \& Martin, 2010). Unlike R\&D, externally acquired technology does not always require support from an innovation-oriented ICT infrastructure. For example, technology-embedded machinery can be applied to production without extra investment in ICT facilities. Therefore, ICT performs as a moderating tool that does not engage in the mutual reinforcement of technology purchasing.

Hypothesis 3: ICT positively moderates the strength of innovation generated by technology purchasing; the intensity of innovative sales achieved through technology purchasing will be strengthened by innovation-oriented ICT.

\section{Methodology and Data Description}

\subsection{Model Specification}

Firm innovation performance is measured by both product and process innovation. Innovation performance is explained by a series of determinants, including knowledge inputs, the adoption of ICT and firm characteristics (size, industry and region specificities). Given the concealed nature of dependent variables, the Tobit model of estimation will be adopted in predicting the following knowledge functions:

$$
P D_{i}^{*}=A+{ }_{d f} \text { Firmspecifics }+{ }_{d s} \text { Size }_{i}+{ }_{d c} \text { City }_{i}+{ }_{d i} \text { Industry }+{ }_{i}
$$




$$
\begin{aligned}
& P D_{i}= \begin{cases}P D_{i}^{*}, & \text { if } P D_{i}>0 \\
0, & \text { otherwise }\end{cases} \\
& P C_{i}^{*}=A+{ }_{c f} \text { Firmspecifics }+{ }_{c s} \text { Size }_{i}+{ }_{c c} \text { City }_{i}+{ }_{c i} \text { Industry }+k_{i} \\
& P C_{i}= \begin{cases}P C_{i}^{*}, & \text { if } P C_{i}>0 \\
0, & \text { otherwise }\end{cases} \\
& A={ }_{1} x_{1}+{ }_{2} x_{2}+{ }_{3} x_{3}+{ }_{12} x_{1} x_{2}+{ }_{13} x_{1} x_{3}+{ }_{23} x_{2} x_{3}+{ }_{123} x_{1} x_{2} x_{3}
\end{aligned}
$$

The dependent variable $P D_{i}$ in Equation (1) represents the product innovation, defined as the development of new products, the changes in design of established products or the use of new materials or components in the manufacture of established products. ${ }^{5} P C_{i}$ in Equation (2) connotes the measure of process innovation and is defined as a novel method (as a consequence of the use of new techniques or equipment) of achieving an output traditionally obtained in a different way. In process innovation, the final product is not necessarily considered, but the way of introducing the product is improved. $P D_{i}$ and $P C_{i}$ are measured by the percentages of sales arising from new product innovations and process innovations respectively; they are both continuous variables and in logarithm.

Product and process innovations share the same set of determinants. A comprises variables in knowledge input and the adoption of ICT. $x_{1}$ denotes in-house R\&D investments and $x_{2}$ signifies the amount of investment spending on the purchasing of external technology. $x_{s}$ is a dichotomous term representing the adoption of ICT. The potential mediating and moderating effects ICT exerts on innovation are captured by these interactive terms. $\alpha$ and $\beta$ are vectors of coefficients yet to be estimated (for a detailed definition of variables see the following section). $\varepsilon_{i}$ and $k_{i}$ are the disturbance terms.

\subsection{Data and Variables}

The firm-level data as presented in the Investment Climate Survey (ICS) ${ }^{6}$ conducted by the World Bank covers a broad range of topics including infrastructure, economic performance and investment environments. Data collected from China in 2012 is used for the current study. The survey collects information from 25 major cities in China and includes questions about new product and process innovations, R\&D activities and, of particular relevance to this study, information with respect to ICT strategies.

The main focus on innovation as defined by the ICS is consistent with other surveys, such

\footnotetext{
5 Policy Studies Institute, University of Westminster. ‘Small Firms Innovation'. Retrieved 27 May 2010 from http://en.wikipedia.org/wiki/Product_innovation

${ }^{6}$ Enterprise Surveys (http://www.enterprisesurveys.org), The World Bank.
} 
as Community Innovation Surveys (CIS). Innovation is defined according to the successful implementation of new technological knowledge, either in the form of new (or significantly improved) products or services (product innovations) or new processes (process innovations). However, it is worth noting that innovations may refer to technologies that are novel or significantly improved only to the firm in which they are implemented and need not necessarily represent a new invention in the market. Table 1 defines the variables and provides corresponding statistics in summary. After the removal of inadequate values ${ }^{7}$, our final sample includes 1,397 firms distributed across a wide range of regions and industries.

The explanatory variables included in equations (1) and (2) are the adoption of ICT, R\&D inputs and technology purchasing. ${ }^{8}$ In-house R\&D investment includes capital, labor and design costs. Another way for firms to strengthen their technological expertise is to buy technology externally from domestic or international suppliers. Technology purchasing is defined in the questionnaire as the amount that firms spend on the acquisition of technology from external sources. Innovation inputs are measured by innovation intensity or the ratio of innovation expenditure to annual sales. ICT achieves a value of one for firms who reported that ICT (computers, the Internet and software) was frequently adopted by their organization to support improvements in products and services.

\section{Table 1 Summary of variables}

\begin{tabular}{|c|c|c|c|c|c|}
\hline Variable & Definition & Mean & S.D. & Min & Max \\
\hline \multicolumn{6}{|c|}{ Dependent variables } \\
\hline Product inno. & Percentages of sales due to new product innovation & 0.11 & 0.17 & 0 & 1 \\
\hline Process inno. & Percentages of output due to process innovation & 0.14 & 0.17 & 0 & 1 \\
\hline \multicolumn{6}{|c|}{ Independent variables } \\
\hline$R \& D$ & $R \& D$ expenditure as percentage of total sales & 1.56 & 3.73 & 0 & 30 \\
\hline Tech Buy & $\begin{array}{l}\text { Tech. purchasing expenditure as percentage of total } \\
\text { sales }\end{array}$ & 0.37 & 0.48 & 0 & 1 \\
\hline
\end{tabular}

\footnotetext{
${ }^{7}$ Firms with fewer than five employees (3.6\%) have been deleted from our sample. Firms that do not aim at innovating are also filtered out from sample (D'Este et al., 2008, Mohnen and Roller, 2005; Savignac, 2008). Specifically, firms not aiming at innovating do not carry out innovation activities at all and more likely to ignore obstacles to innovation. We assume that non-innovative firms which experienced failure of innovation would encounter at least one of four types of obstacles. Hence, we drop firms which have no new or updated products/services and, at the same time, report none of the chosen obstacles is important. It accounts for $6.2 \%$ of the total sample.

8 The main drawback of the innovation input variable is that it is a flow variable and was observed only in the year 2012 - in other words, the same year in which we observed the innovation output. This means that the lag between investment in research and actual innovation is ignored, along with the lag between product innovation and market acceptance. However, Griliches (1998) reports of some scattered evidence from questionnaire studies that such lags are rather short in the manufacturing since most research expenditure are related to development and applied topics.
} 


\begin{tabular}{|c|c|c|c|c|c|}
\hline ICT & $\begin{array}{l}\text { value } 1 \text { if a firm frequently uses ICT (computer, } \\
\text { internet and software) in product and service } \\
\text { enhancement }\end{array}$ & 0.37 & 0.48 & 0 & 1 \\
\hline \multicolumn{6}{|c|}{ Controlled variables } \\
\hline Foreign & Percentage of foreign ownership & 4.94 & 19.16 & 0 & 100 \\
\hline$S O E$ & Percentage of state ownership & 5.08 & 20.64 & 0 & 100 \\
\hline Export & Percentage of sales were directly exported & 0.09 & 0.22 & 0 & 1 \\
\hline Age & Logarithm of firm's age & 2.44 & 0.52 & 0 & 4.83 \\
\hline Scale & Total number of employees, logarithm & 4.44 & 1.30 & 1.61 & 10.31 \\
\hline
\end{tabular}

Theoretical and empirical studies have identified a whole array of factors explaining innovation performance. Our study controls several variables that potentially dictate firm competitiveness and technological capability. Foreign-owned firms normally have high capital intensity, high quality human capital and efficient management. Many previous studies suggest that foreign firms are more productive and innovative compared to domestic ones (Kimura \& Kiyota, 2007). In contrast, state-owned enterprises (SOEs) are usually renowned for redundant workers and inefficient management; they are less motivated to engage in innovation because the local government takes full responsibility for their production and profit (Zhang, 2014). For this reason, we expect negative innovation effects in SOEs.

Export activities are expected to enhance economic growth and improve the productivity of involved firms (Bhagwati, 1988). Firms participating in export are exposed to intense competition in international markets and more vigorous competition exerts pressure on firms in regard to innovation. Therefore, participation in the export market tends to strengthen firm efficiency and signify positive innovation effects (Wagner, 2012). Firm size is measured by the mean of number of employees in logarithm. In accordance with Schumpeter, firm size has been included as a control variable. Logarithm scale is measured by the total number of employees at the end of 2013 and captures the scale effect of innovation. Age is calculated on the basis of the number of years between 2013 and the date that each enterprise started production. Young firms are expected to be more dynamic and flexible when undertaking changes (Katrak, 1997) and therefore a negative effect is expected. Industrial and regional effects are indicated by their corresponding dummies. 


\section{Empirical Evidence: The Role of ICT in Stimulating Innovation}

\subsection{Knowledge Creation in Chinese Manufacturing Firms}

Table 2 presents descriptive statistics corresponding to innovation performance, technology sourcing and firm characteristics. The upper and lower rows are distinguished by the type of innovator, product and process. As the summary statistics show, firms that actively adopt in-house R\&D and ICT are more likely to become innovators compared to firms that purchase technologies externally. Further, engaging in product innovation could also help firms to achieve higher sales as a result of process innovation and vice versa. As for innovation inputs, Chinese firms tend to spend more purchasing technology, despite a lack of innovators among them. Regarding firm characteristics, a clear pattern is shown delineating innovators and non-innovators. Product innovators in general have greater foreign ownership, a larger share of total sales as exports, more employees and longer operational experience compared to firms with poor product innovation. Regarding SOEs, firms with a higher percentage of state ownership tend to be less innovative. A similar distribution can be observed for process innovation in the lower panel of Table 2.

Table 2 Factors explaining the innovativeness of Chinese manufacturing firms

\begin{tabular}{|c|c|c|c|c|c|c|c|c|c|c|}
\hline & $\begin{array}{l}\text { Prod } \\
\text { inno. }\end{array}$ & $\begin{array}{l}\text { Proc. } \\
\text { Inno. }\end{array}$ & R\&D & ICT & BUY & Foreig & SOE & Export & Age & Scale \\
\hline \multicolumn{11}{|l|}{ Product inno. } \\
\hline Product $==0$ & & 0.09 & 0.52 & 0.28 & 4.62 & 4.07 & 7.24 & 0.07 & 2.44 & 4.21 \\
\hline Product $==1^{9}$ & & 0.20 & 2.86 & 0.49 & 4.41 & 6.02 & 2.39 & 0.10 & 2.45 & 4.72 \\
\hline $\begin{array}{l}\text { T-test } \\
\text { H0: diff = } 0\end{array}$ & & $\begin{array}{l}-12.63 \\
* * *\end{array}$ & $\begin{array}{l}-12.24 \\
* * *\end{array}$ & $\begin{array}{l}-8.55 \\
* * * \\
\end{array}$ & 0.68 & $\begin{array}{l}-1.90 \\
*\end{array}$ & $\begin{array}{l}4.39 \\
* * * \\
\end{array}$ & $\begin{array}{l}-2.36 \\
* * \\
\end{array}$ & -0.59 & $\begin{array}{l}-7.34 \\
* * * \\
\end{array}$ \\
\hline \multicolumn{11}{|l|}{ Process inno. } \\
\hline Process $==0$ & 0.03 & & 0.51 & 0.22 & 5.01 & 2.99 & 9.86 & 0.06 & 2.43 & 4.15 \\
\hline Process $==1$ & 0.15 & & 2.13 & 0.46 & 4.27 & 5.99 & 2.49 & 0.10 & 2.45 & 4.60 \\
\hline $\begin{array}{l}\text { T-test } \\
\text { H0: } \text { diff = } 0\end{array}$ & $\begin{array}{l}-12.39 \\
* * * \\
\end{array}$ & & $\begin{array}{l}-7.93 \\
* * * \\
\end{array}$ & $\begin{array}{l}-9.07 \\
* * * \\
\end{array}$ & $\begin{array}{l}2.25 \\
* * \\
\end{array}$ & -2.81 & $\begin{array}{l}6.47 \\
* * * \\
\end{array}$ & $\begin{array}{l}-3.00 \\
* * *\end{array}$ & -0.88 & $\begin{array}{l}-6.27 \\
* * * \\
\end{array}$ \\
\hline
\end{tabular}

To understand how ICT affects the relationship between innovation inputs and outputs, the estimated moderating and mediating effects of ICT on innovation performance and their predicted coefficients are presented in Table 3. Results are displayed for innovation and process innovation respectively, with standard errors given in parentheses. In the product

\footnotetext{
9 Product here are measured by dichotomous terms taking value 1 if a firm has product innovation during the period under review. It is different from the continuous measure used for the dependent variable. Therefore, the ratio of sales due to product innovation for process innovator in the lower panel $(0.15)$ is different from the ratio of sales due to process innovation for product innovator in the upper panel $(0.20)$.
} 
innovation column, Model 1 and Model 3 contain estimates that do not account for possible terms of interaction between innovation inputs and ICT. In contrast, these interactions are included in Model 2 and Model 4 to represent the potential mediating or moderating effects. Model 5 provides full specifications concerning input sources, R\&D and technology purchasing. The same specifications apply to the process innovations listed in the right-hand column.

Acknowledged as one of the most crucial sources of innovation, in-house R\&D drives the innovation of Chinese firms, directly improving innovation performance in terms of both product and process. The estimated coefficients for $\mathrm{R} \& \mathrm{D}$ are each positive and significant at 99 percent. A proportionate level of innovation has also been found in technology purchasing, despite being much lower in magnitude. Although both internal and external knowledge-acquisition activities are essential to product innovation, it is clear that in-house R\&D investment plays a more important role in strengthening innovation sales compared to externally purchased technology.

ICT's estimated coefficients suggest that, even without taking into account potential interactive effects, ICT significantly contributes to innovation performance and its adoption increases sales as a consequence of both product and process innovation (H1). In terms of ICT adoption, the estimates concerning 'R\&D*ICT' are insignificant in Model 2 and Model 5; conversely, the interactions indicated by 'ICT*Tech Buy' are significant, suggesting ICT may also affect innovation via the purchasing of technology. In contrast to product innovation, 'R\&D*ICT' plays a significant positive role in process innovation, suggesting that ICT has a potential moderating effect in fostering process innovations derived from $R \& D$ investments. 
Table 3 Tobit estimation results: the adoption of ICT in explaining the product and process innovation

\begin{tabular}{|c|c|c|c|c|c|c|c|c|c|c|}
\hline \multirow{3}{*}{ VARIABLES } & \multicolumn{5}{|c|}{ Product Innovation } & \multicolumn{5}{|c|}{ Process Innovation } \\
\hline & \multicolumn{2}{|c|}{ In-house R\&D } & \multicolumn{2}{|c|}{ Technology purchasing } & \multirow{2}{*}{$\frac{\text { Full spec. }}{(5)}$} & \multicolumn{2}{|c|}{ In-house R\&D } & \multicolumn{2}{|c|}{ Technology purchasing } & \multirow{2}{*}{$\frac{\text { Full spec. }}{(10)}$} \\
\hline & (1) & (2) & (3) & (4) & & (6) & (7) & (8) & (9) & \\
\hline R\&D & $\begin{array}{c}0.020 * * * \\
(0.002)\end{array}$ & $\begin{array}{c}0.019 * * * \\
(0.002)\end{array}$ & & & $\begin{array}{c}0.027 * * * \\
(0.003)\end{array}$ & $\begin{array}{c}0.010^{* * *} \\
(0.002)\end{array}$ & $\begin{array}{c}0.007 * * * \\
(0.002)\end{array}$ & & & $\begin{array}{c}0.010 * * * \\
(0.003)\end{array}$ \\
\hline ICT & $\begin{array}{c}0.112 * * * \\
(0.018)\end{array}$ & $\begin{array}{c}0.101 * * * \\
(0.020)\end{array}$ & $\begin{array}{c}0.121 * * * \\
(0.019)\end{array}$ & $\begin{array}{c}0.084 * * * \\
(0.023)\end{array}$ & $\begin{array}{c}0.088 * * * \\
(0.024)\end{array}$ & $\begin{array}{c}0.104 * * * \\
(0.014)\end{array}$ & $\begin{array}{c}0.089 * * * \\
(0.015)\end{array}$ & $\begin{array}{c}0.108 * * * \\
(0.014)\end{array}$ & $\begin{array}{c}0.071 * * * \\
(0.017)\end{array}$ & $\begin{array}{c}0.056^{* * * *} \\
(0.018)\end{array}$ \\
\hline Tech Buy & & & $\begin{array}{c}0.007 * * * \\
(0.002)\end{array}$ & $\begin{array}{c}0.004 * * \\
(0.002)\end{array}$ & $\begin{array}{c}0.005^{* *} * \\
(0.002)\end{array}$ & & & $\begin{array}{c}0.004 * * * \\
(0.001)\end{array}$ & $\begin{array}{c}0.001 \\
(0.001)\end{array}$ & $\begin{array}{c}0.001 \\
(0.002)\end{array}$ \\
\hline R\&D*ICT & & $\begin{array}{c}0.006 \\
(0.005)\end{array}$ & & & $\begin{array}{l}-0.005 \\
(0.006)\end{array}$ & & $\begin{array}{c}0.008 * * \\
(0.004)\end{array}$ & & & $\begin{array}{c}0.007 \\
(0.005)\end{array}$ \\
\hline R\&D*Tech Buy & & & & & $\begin{array}{c}-0.001 * * * \\
(0.000)\end{array}$ & & & & & $\begin{array}{c}-0.000 \\
(0.000)\end{array}$ \\
\hline ICT*Tech Buy & & & & $\begin{array}{c}0.008 * * * \\
(0.003)\end{array}$ & $\begin{array}{l}0.006 * \\
(0.003)\end{array}$ & & & & $\begin{array}{c}0.009 * * * \\
(0.002)\end{array}$ & $\begin{array}{c}0.009 * * * \\
(0.002)\end{array}$ \\
\hline R\&D*ICT*Tech Buy & & & & & $\begin{array}{l}0.001 * \\
(0.001)\end{array}$ & & & & & $\begin{array}{l}-0.000 \\
(0.001)\end{array}$ \\
\hline Foreign ownership & $\begin{array}{c}0.000 \\
(0.000)\end{array}$ & $\begin{array}{c}0.000 \\
(0.000)\end{array}$ & $\begin{array}{c}0.000 \\
(0.000)\end{array}$ & $\begin{array}{c}0.000 \\
(0.000)\end{array}$ & $\begin{array}{c}0.000 \\
(0.000)\end{array}$ & $\begin{array}{l}-0.000 \\
(0.000)\end{array}$ & $\begin{array}{c}0.000 \\
(0.000)\end{array}$ & $\begin{array}{c}0.000 \\
(0.000)\end{array}$ & $\begin{array}{l}-0.000 \\
(0.000)\end{array}$ & $\begin{array}{c}0.000 \\
(0.000)\end{array}$ \\
\hline SOE & $\begin{array}{c}-0.001 * * \\
(0.001)\end{array}$ & $\begin{array}{c}-0.001 * * \\
(0.001)\end{array}$ & $\begin{array}{c}-0.002 * * * \\
(0.001)\end{array}$ & $\begin{array}{c}-0.002 * * * \\
(0.001)\end{array}$ & $\begin{array}{c}-0.002 * * \\
(0.001)\end{array}$ & $\begin{array}{c}-0.002 * * * \\
(0.000)\end{array}$ & $\begin{array}{c}-0.002 * * * \\
(0.000)\end{array}$ & $\begin{array}{c}-0.002 * * * \\
(0.000)\end{array}$ & $\begin{array}{c}-0.002 * * * \\
(0.000)\end{array}$ & $\begin{array}{c}-0.002 * * * \\
(0.000)\end{array}$ \\
\hline Export & $\begin{array}{c}0.026 \\
(0.039)\end{array}$ & $\begin{array}{c}0.025 \\
(0.039)\end{array}$ & $\begin{array}{c}0.049 \\
(0.040)\end{array}$ & $\begin{array}{c}0.046 \\
(0.040)\end{array}$ & $\begin{array}{c}0.022 \\
(0.038)\end{array}$ & $\begin{array}{c}0.071 * * \\
(0.029)\end{array}$ & $\begin{array}{c}0.070^{* *} \\
(0.029)\end{array}$ & $\begin{array}{c}0.078 * * * \\
(0.029)\end{array}$ & $\begin{array}{c}0.077 * * * \\
(0.029)\end{array}$ & $\begin{array}{c}0.068 * * \\
(0.029)\end{array}$ \\
\hline Age & $\begin{array}{l}-0.025 \\
(0.017)\end{array}$ & $\begin{array}{c}-0.024 \\
(0.017)\end{array}$ & $\begin{array}{l}-0.015 \\
(0.017)\end{array}$ & $\begin{array}{l}-0.016 \\
(0.017)\end{array}$ & $\begin{array}{c}-0.022 \\
(0.016)\end{array}$ & $\begin{array}{l}-0.002 \\
(0.012)\end{array}$ & $\begin{array}{l}-0.001 \\
(0.012)\end{array}$ & $\begin{array}{c}0.002 \\
(0.012)\end{array}$ & $\begin{array}{c}0.001 \\
(0.012)\end{array}$ & $\begin{array}{c}0.001 \\
(0.012)\end{array}$ \\
\hline Scale & $\begin{array}{c}0.034 * * * \\
(0.007)\end{array}$ & $\begin{array}{c}0.034 * * * \\
(0.007)\end{array}$ & $\begin{array}{c}0.039 * * * \\
(0.007)\end{array}$ & $\begin{array}{c}0.039 * * * \\
(0.007)\end{array}$ & $\begin{array}{c}0.038 * * * \\
(0.007)\end{array}$ & $\begin{array}{c}0.020^{* * *} * \\
(0.005)\end{array}$ & $\begin{array}{c}0.020 * * * \\
(0.005)\end{array}$ & $\begin{array}{c}0.023 * * * \\
(0.005)\end{array}$ & $\begin{array}{c}0.024 * * * \\
(0.005)\end{array}$ & $\begin{array}{c}0.023 * * * \\
(0.005)\end{array}$ \\
\hline Constant & $\begin{array}{c}-0.183 * \\
(0.102)\end{array}$ & $\begin{array}{l}-0.187 * \\
(0.102)\end{array}$ & $\begin{array}{c}-0.179 * \\
(0.105)\end{array}$ & $\begin{array}{c}-0.183 * \\
(0.104)\end{array}$ & $\begin{array}{c}-0.226 * * \\
(0.101)\end{array}$ & $\begin{array}{c}-0.164 * * \\
(0.078)\end{array}$ & $\begin{array}{c}-0.170 * * \\
(0.078)\end{array}$ & $\begin{array}{c}-0.163 * * \\
(0.078)\end{array}$ & $\begin{array}{c}-0.173 * * \\
(0.078)\end{array}$ & $\begin{array}{c}-0.192 * * \\
(0.077)\end{array}$ \\
\hline Sigma & $\begin{array}{c}0.248 * * * \\
(0.008)\end{array}$ & $\begin{array}{c}0.247 * * * \\
(0.008)\end{array}$ & $\begin{array}{c}0.257 * * * \\
(0.008)\end{array}$ & $\begin{array}{c}0.255^{* * *} * \\
(0.008)\end{array}$ & $\begin{array}{c}0.243 * * * \\
(0.008)\end{array}$ & $\begin{array}{c}0.207 * * * \\
(0.005)\end{array}$ & $\begin{array}{c}0.206^{* * *} * \\
(0.005)\end{array}$ & $\begin{array}{c}0.209 * * * \\
(0.005)\end{array}$ & $\begin{array}{c}0.208 * * * \\
(0.005)\end{array}$ & $\begin{array}{c}0.205^{* * * *} \\
(0.005)\end{array}$ \\
\hline Observations & 1,397 & 1,397 & 1,397 & 1,397 & 1,397 & 1,397 & 1,397 & 1,397 & 1,397 & 1,397 \\
\hline
\end{tabular}


With respect to the control variables, the coefficients of the product and process equations are highly consistent. Given the cumbersome institutional settings of Chinese SOEs, firms with a larger share of government ownership are inflexible and reluctant to change. Therefore, SOE undertaking of innovation plans and activities tends to be inefficient compared to firms with other ownership structures (Zhang, 2014). However, no significant difference is apparent between foreign firms and local firms with respect to innovative sales. This may be because foreign-controlled firms are inclined to concentrate their research and development on their home countries (OECD, 2003). Scale effects have also been observed for product and process innovation. Firms with a large number of employees seem to have more resources to support innovation. Hence, their innovation sales are significantly higher than those with fewer employees. Long operational experience and intensive exports increase innovation sales. Intense competition in the global arena is expected to provide incentive for firms to become innovators. However, China's exporters are accustomed to competing in the international market and offering price advantages on existing products as a consequence of their relatively low input costs. Introducing new products is not their core competitive strategy for gaining access to the global market. This explains why export is not a significant factor in promoting product innovation in China. On the contrary, process innovation, associated with efficiency improvement and cost reduction, helps Chinese export firms to further strengthen their price advantage, as suggested by the coefficients under 'EXPORT' from Models (6)-(10). Young firms are characterized as more dynamic and they are urged to be innovative to survive in a competitive market. Moreover, young firms are more likely to accept new ideas because their company culture is less embedded. Negative signs may be shown in terms of the coefficients of age but such innovation impacts are not statistically significant.

\subsection{Decomposition of the Moderating and Mediating Effects of ICT Adoption}

To understand through which channels and to what extent ICT affects innovation we have differentiated its moderating effects from its mediating effects. Computations of the moderating effect (Baron \& Kenny, 1986) and the mediating effect (Judd \& Kenny, 1981) are presented in Table 4, with standard errors given in parentheses.

The computation of the moderating effect can be ascertained from the interactions in Table $4 .{ }^{10}$ The estimates imply that the adoption of ICT positively moderates external knowledge resulting from the purchase of technology and reinforces its impacts on innovation performance. The purchase of external technology fosters a higher percentage of innovation

${ }^{10}$ See Baron and Kenny (1986) for more details on the detailed computation of moderate effects. 
sales in the presence of ICT than it does without the adoption of ICT (H3 was approved). The same moderating effect was found in process innovation generated from R\&D investment, but not for the product innovation as a consequence of $R \& D$ alone.

Following Baron and Kenny (1986), we have employed two approaches to test the mediating effect of ICT adoption and calculate its potential indirect effect:

$$
\begin{aligned}
& \text { M1: ICT }=a_{1}+b_{1} x+e_{1} \\
& \text { M2: } Y=a_{2}+b_{2} x+e_{2} \\
& \text { M3: } Y=a_{3}+b_{3} x+c I C T+e_{3}
\end{aligned}
$$

$a_{1}$ in Equation M1 is significant, suggesting a linear relationship between the innovation inputs ( $x$ as R\&D or technology purchasing) and the mediator (ICT). The regression coefficient $b_{2}$ in Equation M2 is significant, implying that there is a linear relationship between the independent variable $x$ and the dependent variable $Y$ (referring to product and process innovation). The term $c$ in Equation M3 is significant, suggesting that the mediator ICT helps predict the dependent variable $Y$ and that $b_{3}$, the effect of independent variable $x$ on the dependent variable $Y$, becomes significantly smaller in size relative to $b_{2}$ in Equation M2.

Specifically, the regression coefficient for the indirect effect represents a change in new product sales corresponding to every unit change in innovation input mediated by the adoption of innovation-oriented ICT. The first approach is to directly compute the difference between the two regression coefficients with and without the presence of mediators (see M1 and M2 below) (Judd \& Kenny, 1981). This can be achieved by subtracting the partial regression coefficient obtained in an 'equation with ICT' from a simple regression coefficient obtained from an 'equation without ICT': ${ }^{11} b_{\text {indirect eff. }}=b-b_{3}$.

As proposed by Sobel (1982), the second approach calculates the indirect effect by multiplying two regression coefficients (with and without the presence of a mediator). If either $b_{1}$ or $c$ is insignificant there is said to be no mediation. The Sobel test (Sobel, 1982) is given as follows:

$$
\text { Sobel test }=\frac{b_{1} \times c}{\sqrt{c^{2} s_{b_{1}}^{2}+b_{1}{ }^{2} s_{c}^{2}}}
$$

Here, $s_{b_{1}}^{2}$ is obtained from Equation $\mathrm{M} 1$ and $s_{c}^{2}$ is obtained from Equation M3. Consistent with previous literature (MacKinnon, Warsi \& Dwyer, 1995), the Judd and Kenny (1981) approach employing the difference of coefficients and the Sobel (1982) approach

\footnotetext{
11 The detailed calculation involved in the estimating of some equations not presented in this manuscript, such as a simple equation without ICT adoption variables. The estimation results of this simple equation will be available upon request.
} 
utilizing the product of coefficients yield identical values for the indirect effect. The adoption of innovation-oriented ICT positively mediates both product innovation and process innovation gains in $R \& D$ investment, whereas $R \& D$ reciprocally reinforces the adoption of $\operatorname{ICT}(\mathrm{H} 2)$.

Table 4. Calculating the moderating effects and mediating effects

\begin{tabular}{|c|c|c|c|c|c|}
\hline \multirow[b]{2}{*}{ ICT_Inno } & & \multicolumn{2}{|c|}{ Product innovation } & \multicolumn{2}{|c|}{ Process innovation } \\
\hline & & R\&D & Tech-purchasing & R\&D & Tech-purchasing \\
\hline \multirow{4}{*}{$\begin{array}{l}\text { Moderating } \\
\text { effects }\end{array}$} & R square: Model 1 & 0.4252 & 0.3697 & 0.5373 & 0.5080 \\
\hline & R square: Model 2 & 0.4263 & 0.3755 & 0.5437 & 0.5251 \\
\hline & Interaction with ICT & 0.006 & $0.008 * * *$ & $0.008 * *$ & $0.009 * * *$ \\
\hline & Stand. Err. & $(0.005)$ & $(0.003)$ & $(0.004)$ & $(0.002)$ \\
\hline \multirow{3}{*}{$\begin{array}{l}\text { Mediating } \\
\text { effects }\end{array}$} & Coef. b2 without ICT & $0.020 * * *$ & $0.005 * * *$ & $0.010 * * *$ & $0.003 * *$ \\
\hline & Coef.b1: & $0.022 * *$ & -0.006 & $0.022 * *$ & -0.006 \\
\hline & Coef.c: with ICT & $0.005 * * *$ & $0.005 * * *$ & $0.104 * * *$ & $0.104 * * *$ \\
\hline $\begin{array}{l}\text { Both b1 and } \\
\text { c sig. }\end{array}$ & Coef. b3 & Yes & No & Yes & No \\
\hline $\begin{array}{l}\text { Either b1 or } \\
\text { c sig. }\end{array}$ & $\begin{array}{l}\text { Sobel test: } \\
\text { proportion of } \\
\text { mediating effects }\end{array}$ & $0.028 *$ & -0.029 & $0.064 *$ & -0.054 \\
\hline
\end{tabular}

Standard errors in parentheses $* * * \mathrm{p}<0.01, * * \mathrm{p}<0.05, * \mathrm{p}<0.1$

Notes: coef. b2 is the coefficient of independent variable when estimating without the presence of ICT; Coef. b1 is the coefficient of independent variable when regressing ICT on independent variables and control variables; Coef. $\mathrm{c}$ is the coefficient of independent variable when estimating with the presence of ICT. See equation (4) for more details.

\section{Conclusions and Discussions}

This study investigates the many roles of ICT in innovation. The findings suggest that ICT not only improves the performance of Chinese manufacturing firms by directly contributing to innovation, but also affects innovation outcomes via internal and external innovation strategies. In this regard, ICT facilitates innovation input and becomes a component of the integrated innovation resources that jointly affect innovation outcomes. The results of this study emphasize that ICT induces strong innovation as both a tool enabling knowledge creation and an instrument supporting in-house R\&D and technology purchasing.

Our study further explores the mechanisms by which ICT interacts with these two innovation inputs. Specifically, the mediating and moderating effects of ICT are distinguished and tested in accordance with Baron and Kenny (1986). The results show that innovation-oriented ICT exhibits a mediating effect on R\&D and influences innovation. In other words, innovation-oriented ICT applications strengthen the causality between R\&D and the intensity of innovation sales; further, the likelihood of adopting ICT rises as organizations increase R\&D investment. The absence of ICT in this process may result in significant losses in the sales of new products generated from R\&D. Empirical analysis also identifies the 
moderating role of ICT in the relationship between $R \& D$ investment and process innovation, suggesting that ICT facilitates intense process innovation enabled by in-house R\&D.

In terms of technology purchasing, ICT is an effective moderator for leveraging externally acquired codified knowledge. This finding is consistent with previous studies that suggest ICT improves marginal innovation outputs via capability accumulation and organizational learning (Wiseman \& Anderson, 2012; López-Nicolas \& Soto-Acosta, 2010). Hence, adopting ICT will strengthen the intensity of innovation generated by the purchasing of external technology.

Developing prior research on innovation systems (Woolthuis et al., 2005; Lau et al., 2013), this study offers a better understanding of organizational innovation by developing an analytical framework to address the potential interactions of key inputs into innovation. It proposes that ICT performs as a multifaceted enabling tool in ecosystems that are generative of innovation and interacts with other technology sources. Depending on technology-acquisition strategies and on the ways in which the innovation-oriented ICT interacts with these strategies, the innovation outcomes are different. To maximize the innovation outcomes, organization managers need to adopt appropriate ICT strategies and allocate innovation resources effectively by taking into account their multifaceted roles.

Although both product and process are equally important considerations for innovation, previous studies rarely address the innovative performance function of the latter. After quantitatively estimating the determinants of sales arising from process innovation, we found that $R \& D$ is a less effective stimulant of process innovation than it is of product innovation. The channels of mutual influence for ICT, in-house R\&D and technology purchasing also behave differently in respect to product and process innovation. Accordingly, it is recommended that any formalization of organizational innovation strategies takes into account these differences.

Several limitations need to be noted. This study has not addressed the theoretical properties of product and process innovation, such as governance structure, scope and motivation. The exclusion of these properties may increase the possibility of bias as a consequence of missing variables. Another limitation is that these research findings are unlikely to be generally applicable in other contexts because of the limited scope of the data. In particular, industrial heterogeneity should be further addressed in future studies, as opposed to the reliance on industry dummies for controls that was necessary to this study. Technological industries would likely perform differently and be determined by different 
factors compared to non-technological industries. Finally, the cross-sectional nature of the data may cause unintentional bias arising from unobserved and unaccounted for heterogeneity. Robust and insightful analyses require the availability of longitudinal data across a greater coverage of regions with a standardized questionnaire.

\section{References}

A.Ollo-López, M.E. Aramendía-Muneta.(2012). ICT impact on competitiveness, innovation and environment. Telematics and Informatics, 29, 204-210.

Aiken, L. S., \& West, S. G. (1991). Multiple regression: Testing and interpreting interactions. Newbury Park, CA: Sage.

Bafoutsou, G., \& Mentzas, G. (2002). Review and functional classification of collaborative systems. International Journal of Information Management, 22(4), 281-306.

Bakhshi, H., Larsen,J. (2005). ICT-specific technological progress in the United Kingdom. Journal of Macroeconomics, 27, 648-669.

Baron, R. M., \& Kenny, D. A. (1986). The moderator-mediator variable distinction in social psychological research: Conceptual, strategic and statistical considerations. Journal of Personality and Social Psychology, 51, 1173-1182.

Bhagwati J.N (1988). Export-Promoting Trade Strategy: Issues and Evidence, World Bank Research Observer, 3(1), 27-57.

Bresnahan T.F., Brynjolfsson E. \& Hitt L.M. (2002). Information technology, workplace organization, and the demand for skilled labor: Firm-level evidence, The Quarterly Journal of Economics, 117(1), 339-376.

Chen, C., Watanabe,C., Griffy-Brown, C.(2007). The co-evolution process of technological innovation-An empirical study of mobile phone vendors and telecommunication service operators in Japan. Technology in Society, 29, 1-22.

Christensen, J.F., Maskell, P. (eds).(2003).The Industrial Dynamics of the New Digital Economy. Cheltenham: EdwardElgar.

Cohen, W. M., Levinthal, D. A. (1990). Absorptive capacity: A new perspective on learning and innovation. Administrative Science Quarterly, 35, 128-152.

Corrocher, N., Malerba, F., Montobbio, F.(2007).Schumpeterian patterns of innovative activity in the ICT field. Research Policy, 36, 418-432.

Gao G., Hitt L. M., (2012). Information Technology and Trademarks: Implications for Product Variety. Management Science, 58(6),1211-1226.

Girotra, K., C. Terwiesch, K. T. Ulrich. (2007). Valuing R\&D projects in a portfolio: Evidence from the pharmaceutical industry. Management Science, 53(9), 1452-1466.

Hall, B.H., Lotti, F. and J. Mairesse (2012): Evidence on the Impact of R\&D and ICT Investments on Innovation and Productivity in Italian Firms, Economics of Innovation and New Technology, 22(3), 300-328.

Henderson, R., Cockburn, I. (1996). Scale, scope, and spillovers: The determinants of research productivity in drug discovery. Rand Journal of Economics, 27(1), 32-60. 
Hicks D, Katz J S.(1996). Science policy for a highly collaborative science system. Science and Public Policy, 23: 39-44.

Hidalgo A. \& López V. (2009). Drivers and impacts of ICT adoption on transport and logistics services, Asian Journal of Technology Innovation, 17(2), 27-47

Jalava J., Pohjola M. (2007). ICT as a source of output and productivity growth in Finland. Telecommunications Policy, 31(8-9), 463-472.

Jorgenson, D.W. and Nomura K. (2005). The Industry Origins of Japanese Economic Growth, Journal of Japanese and International Economies. 19, 482-542.

Judd, C.M. \& Kenny, D.A. (1981). Process Analysis: Estimating mediation in treatment evaluations. Evaluation Review, 5(5), 602-619.

Kang K. H., Jo G. S. \& Kang J.(2015). External technology acquisition: a double-edged sword, Asian Journal of Technology Innovation, 23(1), 35-52.

Katrak H. (1997). Developing countries' imports of technology, in-house technological capabilities and efforts: an analysis of the Indian experience, Journal of Development Economics, 53(1):67-83.

Kimura, F. and K. Kiyota.(2007). Foreign-owned versus domestically-owned firms: Economic performance in Japan, Review of Development Economics, 11(1):31-48.

Lai H. C. \& Weng C. S. (2016). Exploratory innovation and exploitative innovation in the phase of technological discontinuity: the perspective on patent data for two IC foundries, Asian Journal of Technology Innovation, 24(1), 41-54

LauA. K.W. , Baark E., Lo W. L.W., Sharif N. (2013). The effects of innovation sources and capabilities on product competitiveness in Hong Kong and the Pearl River Delta, Asian Journal of Technology Innovation, 21 (2), 220-236.

Lee S, Kim M.S., Park Y. (2009). ICT Co-evolution and Korean ICT strategy-An analysis based on patent data (2009).Telecommunications Policy, 33, 253-271.

Liberatore, M. J., Stylianou A. C. (1995). Expert support systems for new product development decision making: A modeling framework and applications. Management Science, 41(8), 1296-1316.

Loehlin, J. C. (1987). Latent variable models: An introduction to factor, path and structural analysis. Mahwah, NJ: Lawrence Erlbaum Associates.

Lopez-Nicolas C, Soto-Acosta P.(2010). Analyzing ICT adoption and use effects on knowledge creation: An empirical investigation in SMEs. International Journal of Information Management, 30: 521-528.

Nepelski D. \& Prato G. D. (2012). Internationalisation of ICT R\&D: a comparative analysis of Asia, the European Union, Japan, United States and the rest of the world, Asian Journal of Technology Innovation, 20(2), 219-238.

Nguyen T. U. T., Martin L. (2010). An The Relationship between Innovation and Productivity conditional to $R \& D$ and ICT use: an empirical analysis for firms in Luxembourg, Paper for the 3rd Vietnam Economist Annual Meeting (VEAM), August 24 and 25, 2010.

Nonaka, I., D.J. Teece (editors).(2001). Managing industrial knowledge, creation, transfer, and utilization, Sage Publications, p. 280.

OECD (2010a). Are ICT Users More Innovative? An Analysis of ICT-enabled Innovation in OECD Firms. DSTI/ICCP/IIS(2010)8/REV1.

Oladipo O. S., Andrew O. D. (2012). Information and Communication Technology (ICTs) as a Tool for Innovation. Advances in Natural Science, 5(2): 71-75.

Pepper G. L., Larson G. S. (2006). Overcoming Information Communication Technology Problems in a Post-Acquisition Organization. Organizational Dynamics, 35(2):160-169.

Rao N.H. (2007). A framework for implementing information and communication technologies in agricultural development in India. Technological Forecasting \& Social Change, 74:491-518.

Shin J., Park Y. (2007). Building the national ICT frontier: The case of Korea, Information Economics \& Policy, 2(2), 249-277. 
Sobel, M. E. (1982). A symptotic confidence intervals for indirect effects in structural equation models. In S. Leinhardt (Ed.), Sociological Methodology 1982 (pp. 290-312). Washington DC: American Sociological Association.

Sorenson, O.,Rivkin,J.,\& Fleming,L.(2006).Complexity, networks and knowledge flow. Research Policy, 35, 994-1017.

Tafti A, Mithas S., Krishnan M. S.(2013) The Effect of Information Technology-Enabled Flexibility on Formation and Market Value of Alliances. Management Science, 59(1), 207-225.

Takahashi, K.I., Tatemichi, H., Tanaka, T., Nishi, S., Kunioka, T. (2004). Environmental impact of information and communication technologies including rebound effects, International Symposium on Electronics and the Environment (ISEE'04), 13-1.

Tambe P., Hitt L.M.(2012). Now IT's Personal: Offshoring and the Shifting Skill Composition of the U.S. IT Workforce, Management Science, 58(4), 678-695.

Wagner J. (2012). Trading Many Goods with Many Countries: Exporters and Importers from German Manufacturing Industries, Working Paper Series in Economics, Leuphana Universität Lüneburg , http://www.econstor.eu/dspace/escollectionhome/10419/155.

Wiseman A.W., Anderson E.(2012). ICT-integrated education and national innovation systems in the Gulf Cooperation Council (GCC) countries. Computers \& Education, 59 (2012) 607-618.

Woolthuis K.,Lankhuizen M., \& Gilsing V.(2005). A system failure framework for innovation policy design. Technovation, 25, 609-619.

Yu L, Suojapelto K, Hallikas J, Tang O.(2008). Chinese ICT industry from supply chain perspective- A case study of the major Chinese ICT players. International Journal of Production Economics, 115, 374-387.

Zack M.H. (1999). Developing a Knowledge Strategy, California Management Review, 41(3), 125-145.

Zhang ZX (2014). Energy Prices, Subsidies and Resource Tax Reform in China, Asia \& the Pacific Policy Studies, 1(3), 439-454.

Ziesemer T. (2002). ICT as Technical Change in the Matching and Production Functions of a Pissarides-Dixit-Stiglitz model, Research Memorandum, available from https://www.researchgate.net/publication/4869307_ICT_as_Technical_Change_in_the_Matching_and _Production_Functions_of_a_Pissarides-Dixit-Stiglitz_model 